\title{
Anthropic transformation in the Gurupi river basin, eastern Amazon
}

\author{
Transformação antrópica na bacia hidrográfica do rio \\ Gurupi, Amazônia oriental \\ Fabiana da Silva Pereira ${ }^{a}$ \\ Ima Célia Guimarães Vieira ${ }^{b}$ \\ ${ }^{a}$ Mestre em Ciências Ambientais, Museu Paraense Emílio Goeldi-MPEG, Belém, PA, Brasil. \\ E-mail: ambiental.fabiana@hotmail.com \\ ${ }^{b}$ Doutora em Ecologia, Museu Paraense Emílio Goeldi-MPEG, Belém, PA, Brasil. \\ E-mail:ima@museu-goeldi.br
}

doi:10.18472/SustDeb.v10n3.2019.23799

Received: 21/03/2019

Accepted: 02/12/2019

ARTICLE- DOSSIER

\begin{abstract}
The objective of this paper was to evaluate the degree of anthropic transformation of a river basin in the Amazon region. We used the digital data of the TerraClass Project to calculate the Anthropic Transformation Index - ATI. In order to verify spatial and temporal changes along a decade in the Gurupi river basin, we used the database of the years 2004 and 2014. The results showed an increase of anthropic changes in the basin over a decade, as a result of forest cover conversion into agricultural and pastures areas. Although the Gurupi river basin remains at a regular level of degradation after a decade, the intensification of land use and land cover change is a threat to the few rainforest remnants of the river basin, which can lead the region to the next level of degradation, if effective forest protection, conservation and restoration actions are not implemented in the region.
\end{abstract}

Keywords: Land uses. Anthropic alteration. Degradation. Amazon.

\section{RESUMO}

Este artigo tem como principal objetivo avaliar o grau de transformação antrópica de uma bacia hidrográfica amazônica. Para isso, foram utilizados dados do projeto TerraClass e aplicado o Índice de Transformação Antrópica - ITA para os anos de 2004 e 2014, a fim de verificar as mudanças espaciais ao longo de uma década. Os resultados mostraram que houve uma intensificação no nível de antropização da bacia do rio Gurupi ao longo dos dez anos avaliados, resultado da conversão de áreas de florestas para a expansão de atividades agropecuárias. Embora esta bacia possua um nível de degradação considerado 
regular, as intensas mudanças no uso e cobertura do solo da bacia constitui-se em uma ameaça direta aos poucos remanescentes de floresta madura ainda existentes, o que elevaria a região a um próximo patamar de degradação, se não houver ações de proteção, conservação e restauração florestal.

Palavras-Chave: Usos da terra. Alteração antrópica. Degradação. Amazônia.

\section{INTRODUCTION}

River basins are complex systems, understood as key management units for the planning and administration of water resources and land use. River basins are easy to recognize and characterize, and studies based on this type of spatial cutout allow an integrated approach to the environment (MOLLE, 2009). Despite their importance the lack of planning and management associated with the effects of unsuitable land use and indiscriminate use of water threaten the maintenance and sustainability of watersheds in Brazil.

The Amazon basin is the largest hydrographic basin on the world and the recent occupation of the region with the explicit objective of securing national borders and integrating the region's economy, has led to large-scale deforestation and land use changes, with negative consequences in terrestrial and aquatic ecosystems (VAL et al., 2010; FEARNSIDE, 2005). In the eastern Brazilian Amazon the history of human colonization and the intense dynamics of land use and occupation since the nineteenth century, have contributed to the anthropization of the landscape, which has been accelerated over the last 50 years due to predatory selective logging and extensive cattle ranching, determinants for changes in the forest landscape of the region (ALMEIDA and VIEIRA, 2010; CELENTANO et al., 2018).

Despite the efforts to monitor deforestation in the Amazon (INPE, 2016), the most complete mapping of land use in deforested areas started to be produced by the TerraClass project (COUTINHO et al., 2013; ALMEIDA et al., 2016) based on high resolution images and remote sensing and geoprocessing techniques. TerraClass data combined with other tools that assess anthropogenic changes in the landscape, represent an important instrument to help managing and controlling the environmental degradation of watersheds. The Anthropic Transformation Index (ATI) has a good performance to assess the pressures of economic activities on landscape components, and thus quantifies its current degree of degradation (GOUVEIA; GALVANIN; NEVES, 2013; RODRIGUES et al., 2014; PERIM and COCCO, 2016; RIBEIRO, GALVANNIN and PAIVA, 2017; ORTEGA, 2017; ALMEIDA and VIEIRA, 2019).

The Gurupi river basin is particularly relevant to the regional environmental scenario due to its socio-environmental and political importance, as it corresponds to the border between the states of Pará and Maranhão, at the Amazon agricultural frontier. In the present study, we evaluated the degree and dynamics of anthropization in the Gurupi river basin over a decade (2004-2014), integrating efforts to support strategies for territorial protection of this basin.

\section{MATERIALS AND METHODS}

\subsection{STUDY AREA}

The Gurupi river basin has a length of about $35000 \mathrm{~km} 2$ and is located between the states of Pará and Maranhão. Its main river, the Gurupi river, is a natural physical divider between the two states (FIGURE 1). With a length of approximately $700 \mathrm{~km}$, this river springs in the Serra do Gurupi, in the municipality of Açailândia - Maranhão, and flows into the Atlantic Ocean (UEMA, 2016). 

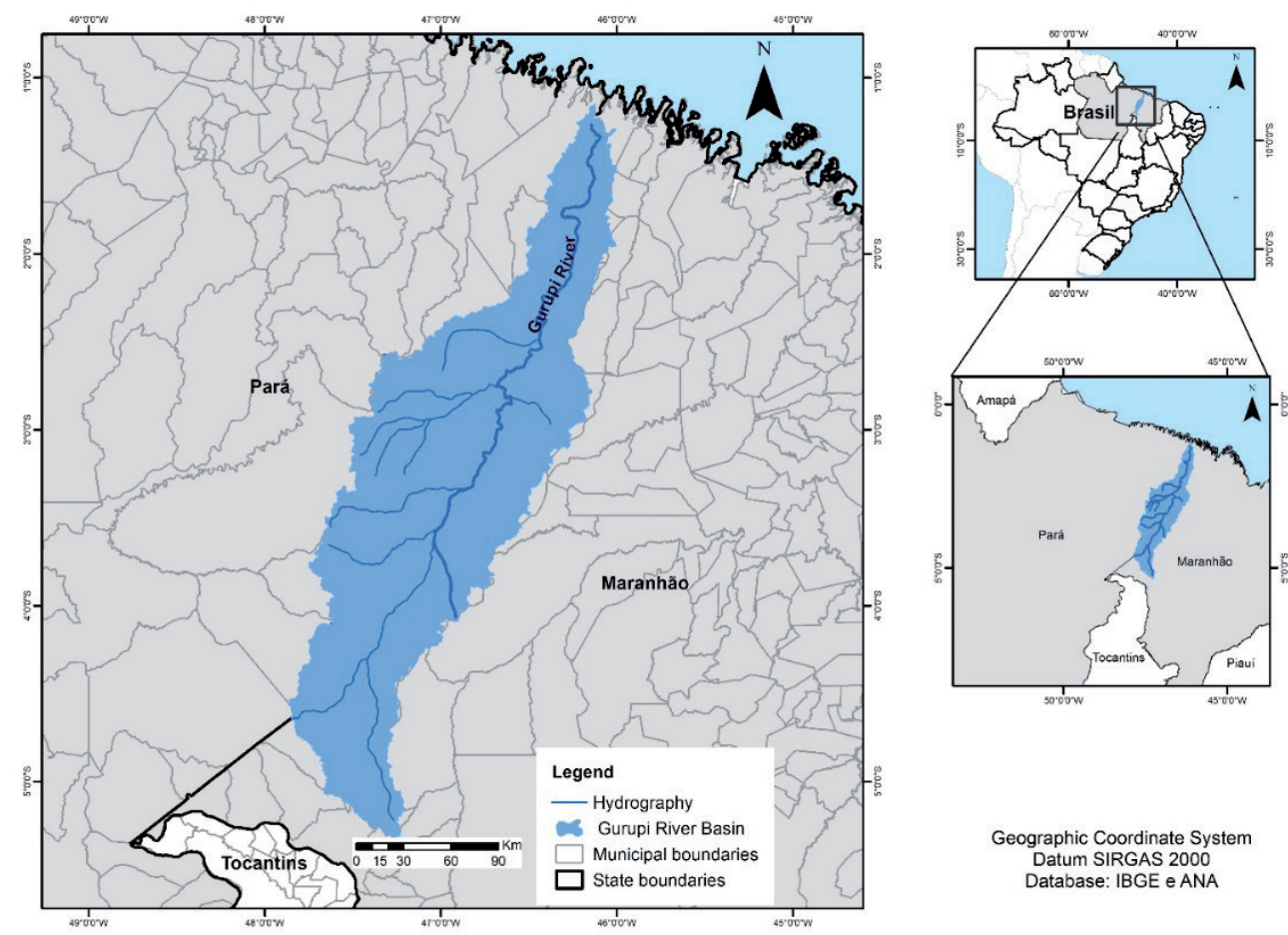

Figure 1 | The Gurupi river basin, Eastern Amazon.

Source: Cartographic database of the Brazilian Institute of Geography and Statistics (In Portuguese: Instituto Brasileiro de Geografia e Estatistica - IBGE) and the National Water Agency of Brazil (In Portuguese: Agência Nacional das Águas - ANA) (2019).

The Gurupi river basin is part of the Western Northeast Atlantic Hydrographic Region, which encompasses much of the state of Maranhão and a small portion of the state of Pará (ANA, 2015). The Gurupi river basin covers the whole territory of the Itinga do Maranhão and Boa Vista do Gurupi municipalities in the state of Maranhão, and parts of the territorial areas of 12 municipalities: Cachoeira do Piriá, Dom Eliseu, Nova Esperança do Piriá, Paragominas, Ulianópolis and Viseu, in the state of Pará, and also the municipalities of Açailândia, Carutapera, Centro Novo do Maranhão Junco do Maranhão, and São Francisco do Brejão. This region presents a population of 392.601 inhabitants, with $73 \%$ living in urban areas (IBGE, 2010; ANA, 2015). The demographic density of the basin is 10.94 inhab./ $\mathrm{km}^{2}$ (ANA, 2015). In the state of Pará, the density is 6.07 inhab. $/ \mathrm{km}^{2}$ and in Maranhão, 19.81 inhab./ $/ \mathrm{km}^{2}$ (IBGE, 2010).

The border between Pará and Maranhão, in the eighteenth and nineteenth centuries, was composed of numerous farms from which black slaves constantly escaped into the forests, forming the 'mocambos' (village-sized communities mainly of runaway slaves in colonial Brazil, during Portuguese rule) on the banks of the rivers (GOMES, 2005). Thus, various ethnicities and interests were added to the Gurupi region. According to Gomes (2005), the region assumed diverse agricultural and commercial characteristics and these populations made of this region their own borders, marked by countless struggles, alliances and conflicts.

In terms of biogeographic regionalization, the Gurupi basin belongs to the Belém Endemism Area (SILVA et al., 2005), which corresponds to the first frontier of human occupation and agricultural production in the Amazon region and which over the years has led to the conversion of large forest areas into agricultural lands and human settlements (FEARNSIDE, 2005; RIVERO et al., 2009).

This Area of Endemism incorporates all forests and ecosystems east of the Tocantins river in Pará state and includes a greater portion in the state of Maranhão (known as "região da Amazônia Maranhense"). This area has the longest and highest levels of forest loss in Brazilian Amazon, retaining $<20 \%$ of its original primary forest cover and under some kind of protection (ALMEIDA and VIEIRA, 2010; BRAZ et al., 2016), about $10 \%$ are conservation units, and $6 \%$ are indigenous land (SILVA et al., 2005). It is an 
area with about two hundred years of human occupation, where land use changes have caused habitat loss and fragmentation increasing its vulnerability. The few Amazonian forest remnants in the region correspond mainly to indigenous lands and protected areas.

Currently, the Gurupi river basin faces demands for multiple uses, such as urban and rural water supply, industry, irrigation and livestock, and these uses have been under great pressure due to deforestation, exploitation of natural resources and land grabbing (MOURA et al., 2011; CELENTANO et., 2017; CELENTANO et al., 2018). The basin also has low human development and water management indexes, especially in relation to sewage treatment, treated water supply, and efficient water use, with implications for the sustainability of the basin (PNUD, 2013; DIAS et al., 2018).

\subsection{METHODS}

Data from the TerraClass project of the Brazilian National Institute for Space Research (INPE) in partnership with the Brazilian Agricultural Research Corporation (EMBRAPA) were used to identify changes in land use and land cover in the Gurupi river basin (ALMEIDA et al., 2016). The original methodology of the project presents up to 16 land use and land cover classes, implemented for 5 years: 2004, 2008, 2010, 2012 and 2014 (INPE, 2016). However, the years 2004 and 2014 were chosen for the analysis of the present study because they are the earliest and the most recent years of the TerraClass database, and therefore allow to analyze the changes after a decade of mapping.

The ArcGIS tool version 10.2.2 was used for data processing. Initially, a delimitation of the states of Pará and Maranhão was made in the image shape of the basin, and then the classes originally presented by TerraClass were reclassified into 9 classes (FIGURE 2), so as to consider the same classes in the two evaluated years. Four pasture classes were grouped into one, as they corresponded to the same land use, and classes such as mining, deforestation, non-forest and unobserved area were grouped into the "other" class. This was done in order to group the classes that were correlated or unrepresentative. After reclassification, the areas occupied with each class were calculated.

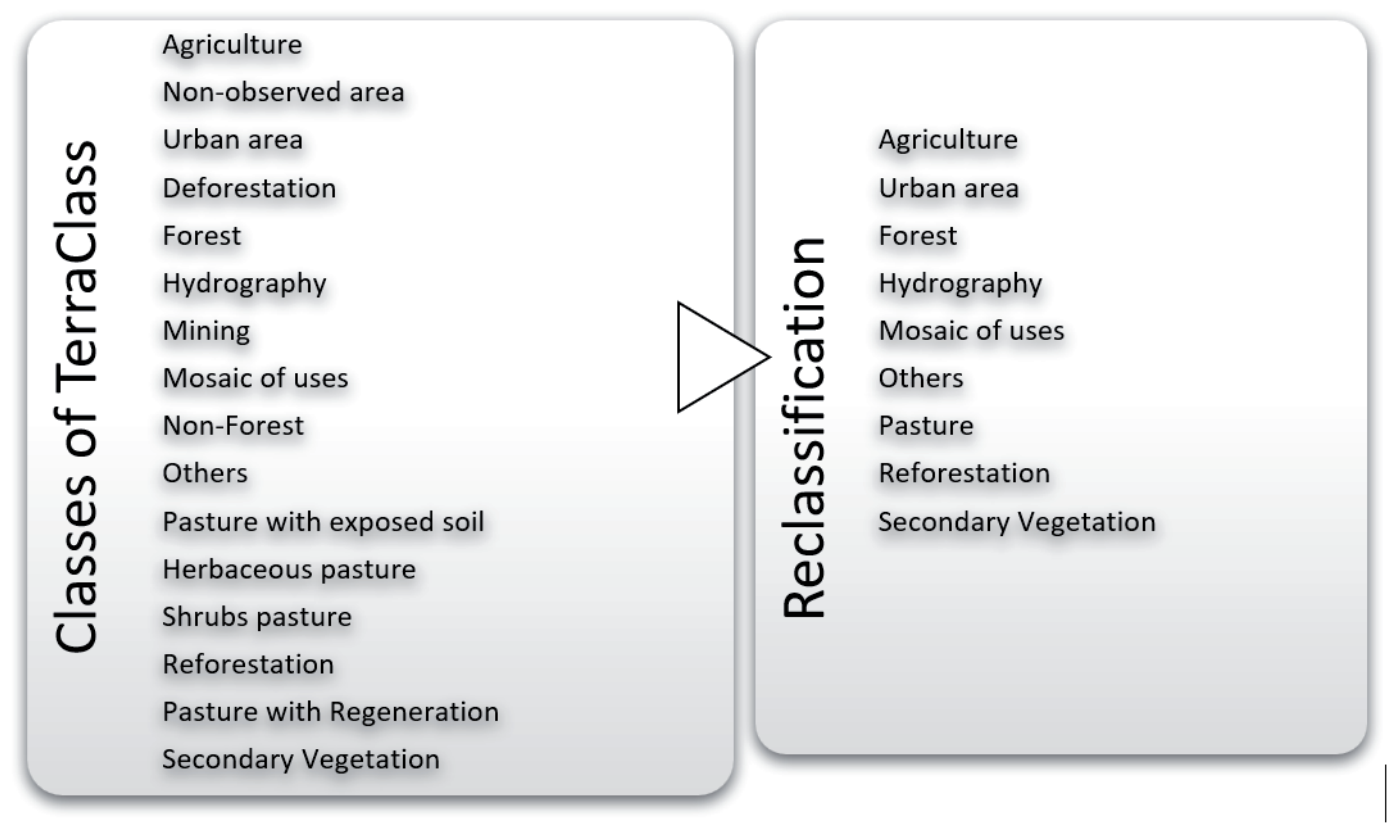

Figure 2 | Reclassification of land use and landcover classes of the TerraClass project. Source: Adapted from TerraClass (2004, 2014). 
The ATI was calculated for the years 2004 and 2014 from the percentage values corresponding to the area of each class of land use and land cover of the basin and their respective weights (GOUVEIA; GALVANIN; NEVES, 2013; RODRIGUES et al., 2014; LEANDRO and ROCHA, 2019):

$$
\mathbf{I T A}=\sum_{i=1}^{n}(r i \mathrm{pi}) / 100
$$

\section{where:}

$\mathrm{ri}=$ weight given to the different $\mathrm{i}$ classes of land use and land cover as a degree of anthropic transformation;

pi $=$ area (\%) of a given land use and land cover class in the basin;

$n=$ number of classes.

The adopted weights were defined based on consultations with specialists in the area, from the Botany and Earth Sciences coordination departments of the Emilio Goeldi Museum, Belém, Pará, according to the Delphi method, which assigns weights and grades based on the knowledge and multidisciplinary view of experts (NOGUEIRA et al., 2001; SCHWENK and CRUZ, 2008; ALMEIDA and VIEIRA, 2019). Weights were assigned according to the degree of modification that a particular class of use and cover exerts on the landscape. These weights vary within a scale from 1 to 10 , from lowest to highest pressure, respectively (Table 1 ).

Table 1 | Land use and land cover classes and their assigned weights in relation to the degree of alteration used in the analysis of the Gurupi river basin, Eastern Amazon.

\begin{tabular}{|c|c|}
\hline Land Use/Cover Classes & Weights \\
\hline AGRICULTURE & 9 \\
\hline PASTURE & 9 \\
\hline URBAN AREA & 10 \\
\hline MOSAIC OF USES & 5 \\
\hline FOREST & 1 \\
\hline HYDROGRAPHY & 1 \\
\hline SECONDARY VEGETATION & 2 \\
\hline OTHERS & 1 \\
\hline REFORESTATION & 5 \\
\hline
\end{tabular}

Source: Authors (2019).

To qualify the basin in relation to its anthropization levels, the following classification was adopted: 0 - 2.5 (slightly degraded), 2.5 - 5 (regular), 5 - 7.5 (degraded), and 7.5 - 10 (very degraded) (CRUZ et al., 1998).

In order to make comparisons of the transformations in the river basin at spatial scale, we analysed the degree of anthropic transformation in the portion of each state, Pará and Maranhão in both periods, 
as well as in the portion that corresponds to the protected areas of the basin (indigenous lands and conservation units).

\section{RESULTS AND DISCUSSION}

The predominant class in the Gurupi basin was forest, both in 2004 and 2014, followed by pasture (FIGURE 3). However, there was a decrease in forest area and an increase in pasture area in the analyzed period.

The development model implemented in the Amazon for obtaining economic advantages only have resulted in intense land occupation associated with land use changes and high pressure on forests. Excessive demand for timber resources combined with an economic strategy that promoted the expansion of livestock and agricultural and agro-industrial commodities from the 1970s onwards has led to systematic deforestation of large forest areas in this region (FEARNSIDE, 2005; RIVERO et al., 2009; ALMEIDA and VIEIRA, 2010; VIEIRA; TOLEDO; HIGUCHI, 2018). Over ten years, forest areas in the Gurupi basin had a decrease of about $2638 \mathrm{~km} 2$, representing a loss of $16 \%$. In turn, the pasture class had an increase of $959 \mathrm{~km} 2,9 \%$ higher compared to 2004 (TABLE 2).

a

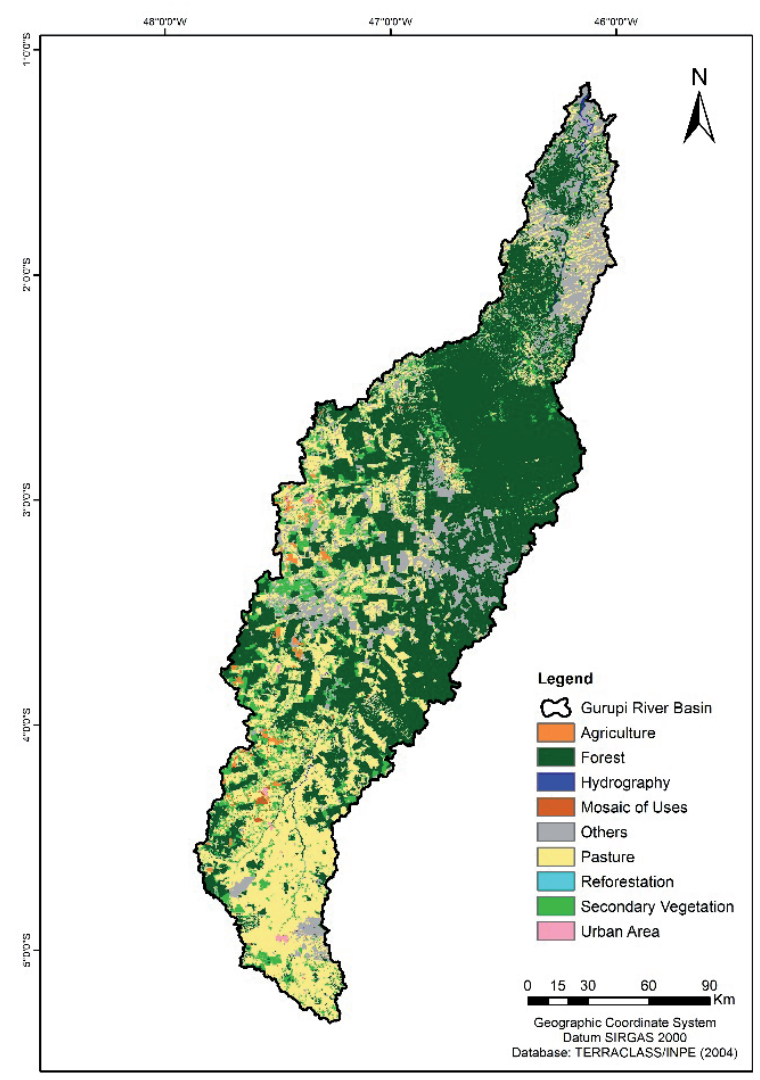

b

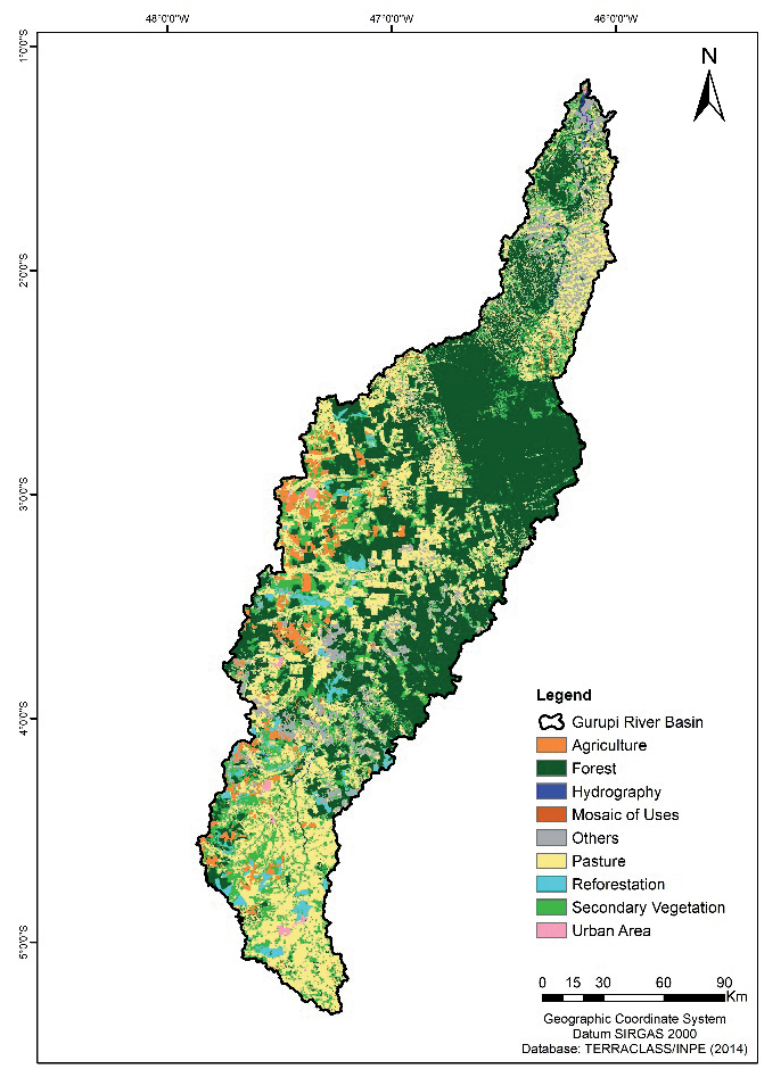

Figure 3 | Map of land use and land cover in the Gurupi river basin, between the states of Pará and Maranhão, in 2004 (a) and 2014 (b).

Source: Prepared by the authors based on TerraClass data (2019). 
Table 2 | Anthropic Transformation Index of the Gurupi River Basin in 2004 and 2014.

\begin{tabular}{|c|c|c|c|c|c|c|}
\hline \multirow{2}{*}{ Land Use/Cover Classes } & \multicolumn{2}{|c|}{ Area $\left(\mathrm{Km}^{2}\right)$} & \multicolumn{3}{c|}{ Area (\%) } & \multicolumn{3}{c|}{ ATI } \\
\cline { 2 - 7 } & 2004 & 2014 & 2004 & 2014 & 2004 & 0,014 \\
\hline AGRICULTURE & 271,33 & 1349,80 & 0,78 & 3,87 & 0,07 & 0,35 \\
\hline PASTURE & 9610,07 & 10569,20 & 27,52 & 30,27 & 2,48 & 2,72 \\
\hline URBAN AREA & 53,34 & 137,00 & 0,15 & 0,39 & 0,02 & 0,04 \\
\hline MOSAIC OF USES & 134,19 & 221,59 & 0,38 & 0,63 & 0,02 & 0,03 \\
\hline FOREST & 16933,00 & 14294,70 & 48,49 & 40,94 & 0,48 & 0,41 \\
\hline HYDROGRAPHY & 61,30 & 61,30 & 0,18 & 0,18 & 0,00 & 0,00 \\
\hline $\begin{array}{c}\text { SECONDARY } \\
\text { VEGETATION }\end{array}$ & 2516,00 & 4357,69 & 7,21 & 12,48 & 0,14 & 0,25 \\
\hline OTHERS & 5339,77 & 3217,33 & 15,29 & 9,21 & 0,15 & 0,09 \\
\hline REFORESTATION & - & 710,39 & - & 2,03 & - & 0,10 \\
\hline TOTAL & & & & & 3,37 & 4,00 \\
\hline
\end{tabular}

Source: Authors (2019).

The agriculture class represented a smaller portion of the basin compared to the pasture class and it had an increase of $1078 \mathrm{~km} 2$ in 10 years, and occupied an area in 2014 about 5 times larger than in 2004 (TABLE 2). Also, the urban area had a significant increase in 10 years, although represented only $1 \%$ of the basin. There was also an increase of $87.4 \mathrm{~km} 2$ and $1841.7 \mathrm{~km} 2$ in the areas occupied by the mosaic of uses and secondary vegetation, respectively, from 2004 to 2014.

The application of the ATI to the Gurupi river basin showed an increase in the degree of anthropization of the region from 2004 to 2014 (TABLE 2), but the basin remained in the "regular" degradation category. The main factors leading to the increase in the degree of anthropization are related to the reduction of forest areas to boost agricultural and livestock activities. In fact, the Gurupi forest is rapidly disappearing due to illegal logging, deforestation and livestock (CELENTANO et al., 2018), and the negligence of the State and absence of effective regulatory and control mechanisms intensify land use conflicts and loss of forests in this region.

Although the Gurupi river basin remained with the same level of degradation in 2014 as in 2004 the highest rates of degradation occurred on the western side of the basin, in the state of Pará (TABLE 3). This result is mainly related to the growth of agricultural activities, which occurred with a little more intensity in the state of Pará, where the agricultural area increased from $263.58 \mathrm{~km} 2$ in 2004 to $1187.34 \mathrm{~km} 2$ in 2014, and the pasture area from $4833.41 \mathrm{~km} 2$ to $5474.24 \mathrm{~km} 2$ in the same period. Another important factor which contributed to the largest change in land use in the western side of the basin is that in the eastern part of the state of Maranhão, more than $1 / 3$ of the territory consists of protected areas, which in some ways slow down the advance of the agricultural frontier. Despite constant threats, such as deforestation, illegal logging and fires, these protected areas conserve forest remnants and biodiversity, thereby ensuring essential ecosystem services (CELENTANO et al., 2018; PAIVA et al., 2019). 
Table 3 | Detailed anthropogenic transformation indexes by state and protected areas of the Gurupi river basin in 2004 and 2014.

\begin{tabular}{|c|c|c|c|c|c|c|}
\hline \multirow{2}{*}{ Land Use/Cover Classes } & \multicolumn{2}{|c|}{$G R B-M A$} & \multicolumn{2}{|c|}{$G R B$ - PA } & \multicolumn{2}{|c|}{ PROTECTED AREAS } \\
\hline & Area (\%) & ATI & Area (\%) & ATI & Area (\%) & ATI \\
\hline \multicolumn{7}{|c|}{2004} \\
\hline AGRICULTURE & 0,05 & 0,00 & 1,38 & 0,12 & 0,00 & 0,00 \\
\hline PASTURE & 30,25 & 2,72 & 25,27 & 2,27 & 2,28 & 0,20 \\
\hline URBAN AREA & 0,14 & 0,01 & 0,17 & 0,02 & 0,00 & 0,00 \\
\hline MOSAIC OF USES & 0,11 & 0,01 & 0,61 & 0,03 & 0,02 & 0,00 \\
\hline FOREST & 49,56 & 0,50 & 47,61 & 0,48 & 89,58 & 0,90 \\
\hline HYDROGRAPHY & 0,14 & 0,00 & 0,20 & 0,00 & 0,15 & 0,00 \\
\hline SECONDARY VEGETATION & 4,30 & 0,09 & 9,60 & 0,19 & 1,44 & 0,03 \\
\hline OTHERS & 15,45 & 0,15 & 15,16 & 0,15 & 6,55 & 0,07 \\
\hline REFORESTATION & - & 0,00 & - & 0,00 & - & 0,00 \\
\hline TOTAL & & 3,48 & & 3,27 & & 1,20 \\
\hline \multicolumn{7}{|c|}{2014} \\
\hline AGRICULTURE & 1,03 & 0,09 & 6,21 & 0,56 & 0,00 & 0,00 \\
\hline PASTURE & 32,26 & 2,90 & 28,62 & 2,58 & 5,24 & 0,47 \\
\hline URBAN AREA & 0,36 & 0,04 & 0,42 & 0,04 & 0,00 & 0,00 \\
\hline MOSAIC OF USES & 0,48 & 0,02 & 0,76 & 0,04 & 0,22 & 0,01 \\
\hline FOREST & 42,77 & 0,43 & 39,42 & 0,39 & 85,17 & 0,85 \\
\hline HYDROGRAPHY & 0,14 & 0,00 & 0,20 & 0,00 & 0,15 & 0,00 \\
\hline SECONDARY VEGETATION & 11,55 & 0,23 & 13,25 & 0,27 & 4,58 & 0,09 \\
\hline OTHERS & 9,56 & 0,10 & 8,93 & 0,09 & 4,65 & 0,05 \\
\hline REFORESTATION & 1,85 & 0,09 & 2,19 & 0,11 & 0,00 & 0,00 \\
\hline TOTAL & & 3,90 & & 4,07 & & 1,47 \\
\hline
\end{tabular}

GRB - Gurupi River Basin. MA - Maranhão. PA - Pará.

Source: Authors (2019).

Protected areas represent almost $20 \%$ of the basin area. These areas are comprised of indigenous lands (Alto Guamá River, Alto Turiaçu and Awa Indigenous Lands) and conservation units (Gurupi River Biological Reserve and a small portion of the Environmental Protection Area of Maranhão Reentrances), which also contain large areas of native vegetation. However, the present study showed that there was an increase in the degree of anthropization from 2004 to 2014 in these protected areas (TABLE 3). Over the last 10 years, forest areas in the protected areas have decreased by $5 \%(298 \mathrm{~km} 2)$ due to pastures which increased by about $200 \mathrm{~km} 2$-, mosaic of uses - which increased up to 14 times -, and secondary vegetation.

The largest areas of native forest are found in Indigenous Lands, but much of the remaining forests are highly fragmented and degraded due to recurrent fire and logging events, as well as hunting and exploitation of non-timber products. Some studies in the protected areas of this region corroborate these results, indicating changes in vegetation cover, mainly associated with illegal logging, agriculture, livestock, urban sprawl and infrastructure projects (SILVA et al., 2019; PAIVA et al., 2019). The Gurupi Biological Reserve, the only integral protection conservation unit in the basin, has been the scenario of intense conflicts, driven mainly by illegal wood extraction from the area, resulting in strong pressures on its ecosystems (MOURA et al., 2011). 
The ATI results showed the growth of anthropogenic activities in the protected areas of the Gurupi basin (TABLE 3), despite the restrictions on land use established by the Brazilian current legislation (BRASIL, 1988; SNUC, 2000). Although their results may seem little significant, they are still worrying, since forest disturbances may potentiate the loss of biodiversity, decreasing the conservation value of these forest areas (BARLOW; LENNOX; GARDNER, 2016).

Creation of protected areas is one of the main strategies for biodiversity conservation. Despite the importance that these areas have to control deforestation and to the conservation of the amazonian iodiversity (FERREIRA; VENTICINQUE; ALMEIDA, 2005), strategies aimed only at maintaining forest cover may not reduce anthropogenic disturbances (BARLOW; LENNOX; GARDNER, 2016). Environmental management strategies need to include monitoring deforestation, environmental surveillance, strengthening local governance systems, and protecting forest productive arrangements around protected areas (CURRAN et al., 2004; SOARES FILHO et al., 2005).

Given the accelerated anthropism in the Gurupi basin, new integrated management strategies for this territory should be implemented in order to reinforce land use governance. One of these proposals is the creation of a mosaic of protected areas in the region (CELENTANO et al., 2018), which integrates efforts for territorial protection, forest restoration, and guarantee of the quality of life and rights of indigenous and traditional populations living in this territory.

\section{CONCLUSIONS}

The analysis of land use and land cover of the Gurupi river basin showed regular level of degradation over a decade. The increase in the pasture and agriculture classes and the decrease in forest area directly reflected in the degree of anthropic transformation index for the region. Although we found a regular level of degradation in the Gurupi river basin both in 2004 and 2014, anthropogenic transformations in the landscape have increased over the 10-year period analyzed. Extensive forest areas have been converted into pastures and agricultural areas and the high demand for land in this river basin is a threat to the forest remnants and biodiversity of the region

Significant proportion of forests in the basin are in protected areas. Nevertheless, the degradation of these forests increased between 2004 and 2014 and endanger not only the biodiversity but also the livelihoods of indigenous populations. Forest conservation and restoration strategies associated to public policies to guarantee traditional populations territories need to be implemented in the region since the creation of protected areas alone have not been able to hinder the growth of anthropogenic disturbances in the Gurupi river basin.

\section{REFERENCES}

AGÊNCIA NACIONAL DE ÁGUAS (BRASIL). Conjuntura dos recursos hídricos no Brasil: regiões hidrográficas brasileiras - Edição Especial. -- Brasília: ANA, 2015. 163 p.

ALMEIDA, C.A.; COUTINHO, A.C.; ESQUERDO, J.C.D.M.; ADAMI, M.; VENTURIERI, A.; DINIZ, C.G.; DESSAY, N.; DURIEUX, L.; GOMES, A.R. High spatial resolution land use and land cover mapping of the Brazilian Legal Amazon in 2008 using Landsat-5/TM and MODIS data. Acta Amazonica, v.46, n.3, p. 291-302, 2016.

ALMEIDA, A.S.; VIEIRA, I.C.G. Transformações antrópicas da paisagem agrícola com palma de óleo no Pará. Novos Cadernos NAEA, v. 22, n. 2, p. 9-26, maio-ago 2019.

ALMEIDA, A.S.; VIEIRA, I.C.G. Centro de endemismo Belém: status da vegetação remanescente e desafios para a conservação da biodiversidade e restauração ecológica. Revista de Estudos Universitários, v.36, n.3, p. 95-111, 2010. 
BARLOW, J.; LENNOX, G. D.; GARDNER, T. A, Anthropogenic disturbance in tropical forests can double biodiversity loss from deforestation. Nature, v. 535, p.144-147, Jul. 2016.

BRASIL. Constituição, 1988. Constituição: República Federativa do Brasil. Brasília: Senado Federal, 1988.

BRASIL. Ministério do Meio Ambiente. SNUC - Sistema Nacional de Unidades de Conservação da Natureza: Lei no 9.985, de 18 de julho de 2000; Decreto no 4.340, de 22 de agosto de 2002; Decreto no 5.746, de 5 de abril de 2006. Plano Estratégico Nacional de Áreas Protegidas: Decreto no 5.758, de 13 de abril de 2006 / Ministério do Meio Ambiente. - Brasília: MMA/SBF, 2011. 76 p.

BRAZ, C. L; PEREIRA, J. L. G.; FERREIRA, L. V.; THALÊS, M. C. A situação das áreas de endemismo da Amazônia com relação ao desmatamento e às áreas protegidas. Boletim de Geografia, Maringá, v. 34, n. 3, p. 45-62, 2016.

CELENTANO, D.; MIRANDA, M. V. C.; MENDONÇA, E. N.; ROUSSEAU, G. X.; MUNIZ, F. H.; LOCH, V. C.; VARGA, I. V. D.; FREITAS,L.; ARAÚJO, P.; NARVAES, I. S. ADAMI, M.; GOMES, A. R.; RODRIGUES, J. C.; KAHWAGE, C.; PINHEIRO, M.; MARTINS, M. B. Desmatamento, degradação e violência no "Mosaico Gurupi" - A região mais ameaçada da Amazônia. Estudos avançados, v. 32, n. 92, p.315-p.339, 2018.

CELENTANO, D., ROUSSEAU, G.X., MUNIZ, F.H., VARGA, I. V. D.; MARTINEZ, C., CARNEIRO, M. S., MIRANDA, M. V. C.; BARROS, M. N.; FREITAS, L.; NARVAES, I. S. ADAMI, M.; GOMES, A. R.; RODRIGUES, J.C.; MARTINS, M. B. Towards zero deforestation and forest restoration in the Amazon region of Maranhão state, Brazil. Land Use Policy, v.68, p.692-698, 2017.

COUTINHO, A. C., C. ALMEIDA, A. VENTURIERI, J. C. D. M. ESQUERDO; M. SILVA. Uso e cobertura da terra nas áreas desflorestadas da Amazônia Legal: TerraClass 2008: 1-108. EMBRAPA, Brasília, 2013.

CRUZ, C. B. M. et al. Carga antrópica da bacia hidrográfica da Baía de Guanabara. In: SIMPÓSIO BRASILEIRO DE SENSORIAMENTO REMOTO, 1998, Santos. Anais.... Santos: 1998. p.99-109.

CURRAN, L. M.; TRIGG, S. N.; MCDONALD, A.K.; ASTIANI, D.; HARDIONO Y. M.; SIREGAR, P.; CANIAGO. I.; KASISCHKE, E. “Lowland Forest Loss in Protected Areas of Indonesian Borneo". Science, n. 303, p.1000-1003, 2004.

DIAS, I. C. L.; FRANÇA, V. L; BEZERRA, D. S.; RABÊLO, J. M. M.; CASTRO, A. C. L. Spatial distribution of river basin sustainability indicators in transition region of Northeastern Brazil. Applied Ecology and Environmental Research, v.16, n.4. p.3729-3754, 2018.

FEARNSIDE, P.M. Desmatamento na Amazônia brasileira: História, índices e conseqüências. Megadiversidade, v.1, n.4, p.113-123, 2005

FERREIRA, L. V.; VENTICINQUE, E.; ALMEIDA, S. O desmatamento na Amazônia e a importância das áreas protegidas. Estudos Avançados, v. 19, n. 53, p.157- 166, 2005.

GOMES, F. dos S. A Hidra e os Pântanos: mocambos, quilombos e comunidades de fugitivos no Brasil (séculos XVII-XVIII). São Paulo: Ed. UNESP/Ed. Polis. 2005.

GOUVEIA, R. G. L.; GALVANIN, E. A. S.; NEVES, S.M. A. S. Aplicação do Índice de Transformação Antrópica, na análise multitemporal da Bacia do Córrego do Bezerro Vermelho em Tangará da Serra - MT. Revista Árvore. v.37, n.6, p.1045-1054. 2013.

INSTITUTO BRASILEIRO DE GEOGRAFIA E ESTATÍSTICA (IBGE), 2010. Censo Demográfico de 2010. Disponível em: < https://censo2010.ibge.gov.br/>. Acesso em 28 de dez. 2019. 
INSTITUTO NACIONAL DE PESQUISAS ESPACIAIS (INPE), 2014. Projeto TerraClass: mapeamento do uso e cobertura da terra na Amazônia Legal Brasileira. INPE, Brasília. Disponível em: <http://www.inpe.br/cra/projetos_pesquisas/ dados_terraclass.php>. Acesso em: 30 janeiro 2019.

INSTITUTO NACIONAL DE PESQUISAS ESPACIAIS (INPE), 2016. Projeto PRODES: monitoramento da floresta amazônica brasileira por satélite. Disponível em: <http://www.obt.inpe.br/OBT/assuntos/programas/amazonia/ prodes>. Acesso em: 5 fevereiro 2019.

LEANDRO, G. R. S.; ROCHA, P. C. Expansão agropecuária e degradação ambiental na bacia hidrográfica do rio Sepotuba - Alto Paraguai, Mato Grosso - Brasil. Sociedade \& Natureza, Uberlândia, v.31, p.1-21, 2019.

MATEO, J. Geoecologia de los Paisajes. Universidad Central de Caracas. Monografia. 1991.

MOLLE, F. River-basin planning and management: the social life of a concept. Geoforum, v.40, n.3, p.484-494, 2009.

MOURA, C.W.; FUKUDA, J.C.; LISBOA, E.A.; GOMES, B.N.; OLIVEIRA, S.L.; SANTOS, M.A.; CARVALHO, A.S. \& MARTINS, M.B. A Reserva Biológica do Gurupi como instrumento de conservação da natureza na Amazônia Oriental. In: MARTINS, M. B.; OLIVEIRA, T. G. (Org.) Amazônia maranhense: diversidade e conservação. Belém: MPEG, 2011. p.24-31.

NOGUEIRA, C. R. et al. Classificação de bacias hidrográficas em tabuleiros costeiros através de indicadores provenientes de sensoriamento remoto - estudo de caso em Linhares e Sooretama, ES. In: SIMPÓSIO BRASILEIRO DE SENSORIAMENTO REMOTO, 2001, Foz do Iguaçu. Anais... Foz do Iguaçu: 2001.p.955-958.

ORTEGA, D. J. P. Identificação e avaliação da pressão antrópica no Reservatório Barragem Engenheiro Paulo de Paiva Castro: repercussão sobre as águas superficiais da Bacia do Rio Juqueri, no Município de Mairiporã - SP. 229f. Tese (Doutorado) - Universidade Estadual Paulista Júlio de Mesquita Filho. Instituto de Ciência e Tecnologia, Câmpus de Sorocaba, 2017.

PAIVA, P. F. P. R.; RUIVO, M. L. P.; SILVA JÚNIOR, O. M. S.; MACIEL, M. N. M.; BRAGA, T. G. M.; ANDRADE, M. M. N.; SANTOS JÚNIOR, P. C. ROCHA, E. S.; FREITAS, T. P. M.; LEITE, T. V. S.; GAMA, L. H. O. M.; SANTOS, L. S.; SILVA, M. G.; SILVA, E. R. R.; FERREIRA, B. M. Deforestation in protect areas in the Amazon: a threat to biodiversity. Biodiversity and Conservation, pp 1-20, 2019.

PROGRAMA DAS NAÇÕES UNIDAS PARA O DESENVOLVIMENTO. ATLAS DO DESENVOLVIMENTO HUMANO NO BRASIL 2013. Disponível em:< http://www.atlasbrasil.org. br/2013/pt/o_atlas/o_atlas_/>. Acesso em 28 de nov. 2019.

PERIM, M. A.; COCCO, M. D. A. Efeito das transformações antrópicas às margens do rio Una, Taubaté, São Paulo, Brasil. Revista Ambiente \& Água, Taubaté, v. 11, 2016.

RIBEIRO, H. V.; GALVANNIN, E. A. S.; PAIVA, M. M. Análise das pressões antrópicas na bacia Paraguai/JauquaraMato Grosso. Ciência e Natura, v.39, n.2, p. 378 - 389, 2017.

RIVERO, S.; ALMEIDA, O.; ÁVILA, S.; OLIVEIRA, W. Pecuária e desmatamento: uma análise das principais causas diretas do desmatamento na Amazônia. Nova Economia, v.19, n.1, p..41-66, 2009.

RODRIGUES, L.C.; SILVA, S.M.A.; NEVES, R.J.; GALVANIN, E.A.S.; SILVA, S.J.V. Avaliação do grau de transformação antrópica da paisagem da bacia do rio Queima-Pé, Mato Grosso, Brasil. Revista Brasileira de Ciências Ambientais, n. 32, p. 52-64, 2014.

SILVA, R. S.; BARBOSA, C. O.; MONTEIRO, F. G.; CORREA, D. L.; GOMES, A. S. Análise multitemporal de parte da Reserva do Alto Rio Guamá, Paragominas, PA. Pesquisa Florestal Brasileira, Colombo, v. 39, p. 1-10, 2019. 
SILVA, J. M. C.; A. B. RYLANDS \& G. A. B. FONSECA. O destino das áreas de endemismo da Amazônia. Megadiversidade, v.1 p.124-129, 2005.

SOARES-FILHO, B. S.; NEPSTAD, D. C.; CURRAN, L.; CERQUEIRA, G. C.; GARCIA, R. A.; RAMOS, C. A.; LEFEBVRE, P.; SCHLESINGER, P.; VOLL, E.; McGRATH, D. Cenários de desmatamento para Amazônia. Estudos Avançados, v.19, n.54, p.138-152, 2005.

SCHWENK, L. M.; CRUZ, C. B. M. Conflitos socioeconômico ambientais relativos ao avanço do cultivo da soja em áreas de influência dos eixos de integração e desenvolvimento no Estado de Mato Grosso. Acta Scientarium Agronomy. v. 30, p.501-511. 2008.

UNIVERSIDADE ESTADUAL DO MARANHÃO. UEMA. Centro de Ciências Agrárias. Núcleo Geoambiental. Bacias hidrográficas e climatologia no Maranhão. Universidade Estadual do Maranhão. - São Luís, 2016. 165 p.

VAL, A. L., ALMEIDA-VAL, V. M. F. DE, FEARNSIDE, P. M., SANTOS, G. M. DOS, PIEDADE, M. T. F., JUNK, W. NOVAWA, S. R., SILVA, S. T. DA, \& DANTAS, F. A. DE C. (2010). Amazônia: Recursos hídricos e sustentabilidade. In: Tundisi, J. (ed.). Recursos Hídricos. São Paulo: Academia Brasileira de Ciências e Fundação de Amparo a Pesquisa do Estado de São Paulo.

VIEIRA, I. C. G.; TOLEDO, P. M.; HIGUCHI, H. A Amazônia no Antropoceno. Ciência e Cultura. v.70, n.1, Jan./ Mar. 2018. 